\title{
Diseases of Jews
}

\author{
DENNIS M. KRIKLER \\ M.B. (Cape Town), F.R.C.P.E., M.R.C.P. \\ Consultant Physician, Prince of Wales's General Hospital, London N.15
}

\begin{abstract}
Summary
The relative social and genetic isolation of Jews from other communities, which was much more marked in the past than now, has led to the belief that they are unusually prone to a variety of illnesses. Until the last few decades assessments of the incidence of various diseases among them were usually based on impressions rather than planned surveys or careful analyses, and many misconceptions still persist. It is proposed to consider the present state of knowledge as well as to indicate the historical and social basis for any tendencies for Jews to suffer from, or perhaps to resist, some diseases. No attempt has been made to analyse every single report in which Jewish predisposition to various diseases is mentioned; attention will be focused on those conditions that have received greater attention or from which it is possible to draw meaningful conclusions.
\end{abstract}

\section{Historical}

Until recent years, most reports on diseases in Jews emanated from Europe and America and dealt with what was found in Ashkenazi Jews. It is necessary therefore to define Jewish sub-groups and where possible to consider this classification in relation to more distant historical events (Groen, 1964; Sheba, 1968).

Ashkenazi Jews include those living in Central, West and East Europe and the descendants of those who have migrated from these areas to Israel, North and South America, South Africa and Australia. Just under half the Jewish population of Israel is Ashkenazi. Ashkenazi Jews are descended from those Jews who were deported from Israel to Rome in the first two centuries A.D. (Sheba, 1968). Subsequently, migration took place across the Alps into France, Germany, Poland, Russia and neighbouring countries. Their vernacular was Yiddish, a blend of Mittelhochdeutsch and Hebrew, flavoured by local influences.

Sephardi Jews may have left Israel somewhat later, when the Roman Empire broke up, joining pre-existing communities around the Mediterranean and Balkans, and extending into Spain and Portugal.
Their vernacular was Ladino, based on Spanish. These were the Jews who were expelled from Iberia at the end of the fifteenth century; most settled in the Balkans and North Africa, but some went to Holland and subsequently Great Britain. Sepharad was the Hebrew name for Spain in the Middle Ages; Germany was similarly known as Ashkenaz (Fishberg, 1911).

Oriental Jews, living in the Middle East and even further afield, are probably the descendants of those deported to Babylon in 586 B.C., who did not return to Judea when permitted to do so 54 years later, with periodic reinforcements during subsequent migrations (Ben-Zvi, 1957).

Whether or not the above historical differentiation, which is similar to that cited by others (Gordon, 1965 ) is correct, it provides a useful working basis for the purpose of this survey. With rare exceptions like the original Jews of Rome (Dunn \& Dunn, 1957) and the Iraqi, Kurdish and Caucasian Jews (Sheba, 1968) these groups did not of course remain strictly isolated from the host population, and there were considerable admixtures, especially in Europe (Sheba et al., 1962), as well as loss by assimilation . into the general population. Until the major resettlement of Jews in Israel during the present century, little was done to study population characteristics and sociological differences in these groups, but there have been many investigations recently (Goldschmidt, 1963). Although Jewish populations have tended to remain separate, they have nevertheless acquired many of the characteristics of the peoples among whom they live (Shapiro, 1960).

It is not proposed here to discuss anthropological features or to go into detail about the relative importance of genetic and environmental factors, but these must obviously be assessed in each case. In the past, crowded conditions in the ghettos may have been responsible for the spread of infections; correspondingly, this may have led to the emergence of genetic characteristics that enabled subsequent generations to resist such epidemics better. Consideration of some of the diseases said, believed, or known to predominate in Jews will enable possible aetiological factors to be explored. 


\section{Metabolic disorders}

Diabetes mellitus is widely believed to be excessively frequent in Ashkenazi Jews (Rolleston, 1928; Sorsby \& Sorsby, 1932; Brinn, 1962) but these impressions have not been borne out by careful studies in Israel (Cohen, 1961) and Sweden (Dahlberg, 1952). With continued residence in more prosperous surroundings the previously low incidence in Yemenite Jews rises to approximate that in Ashkenazis (Cohen, 1961). Exceptionally, relative isolates in whom consanguineous marriages are very frequent may manifest an excess of diabetes on this account, e.g. the Sephardic Jews of Rhodesia (Krikler, 1969).

Pentosuria is a benign, recessively-transmitted defect, one of the original inborn errors of metabolism described by Garrod (1908). It occurs almost exclusively in Ashkenazi Jews of Russo-Polish origin, although rare cases have been discovered in non-Ashkenazi Jews (Sheba et al., 1962) and Lebanese non-Jews (Barnes \& Bloomberg, 1953); and recently an isolated case has been encountered in Canada in an Athabascan Indian (Perry \& Finch, 1967). The affected Lebanese families tend to be highly inbred (Khachadurian, 1962; Politzer \& Fleischmann, 1962).

Glycogen storage diseases have been reported from many parts of the world, but in Israel it has been found that the type III disease (amylo-1, 6glucosidase deficiency; limit dextrinosis) was not found in Ashkenazi Jews but that there was an extraordinarily high gene frequency in Jewish immigrants from North Africa (Levin et al., 1967), with autosomal recessive transmission.

Obesity is frequently held to affect Jews more than others (Rolleston, 1928), but whether this is correct has not been proved; if so, environmental factors are probably important.

A number of writers have stated that idiopathic hypercholesterolaemia tends to occur more frequently in Jews (Schaefer et al., 1953) and that this may produce an excess incidence of coronary artery disease (Epstein, Boas \& Simpson, 1957; Epstein, Simpson \& Boas, 1957) but Fredrickson \& Lees (1966) point out that type II hyperlipoproteinaemia is common in many population groups and not especially so in the (Ashkenazi) Jews mentioned in the other studies. Likewise, Brunner \& Manelis (1960) in a study of members of communal settlements in Israel were unable to show there to be any excess of cardiac infarction over that found in English workers. Dreyfus (1953) noted much more coronary artery disease among Ashkenazi than Oriental Jews. It seems likely that the differing results of these studies reflect socio-economic rather than genetic conditions (Epstein, 1967), but the recent work of Vlodaver, Kahn \& Neufeld (1969) poses some questions. They studied the coronary arteries in full-term foetuses, infants and children (who did not die from cardiac disease) and found intimal and musculo-elastic changes in the Ashkenazi, but not in the Yemenite-Jewish or Bedouin subjects. They point out the apparent correlation between these findings and the incidence of ischaemic heart disease in these population groups; the relevance of these changes to the onset of the disease in adult life remains to be shown.

The cerebral sphingolipidoses are not, as sometimes said, confined to Jews, but in the case of Tay-Sachs disease, infantile Niemann-Pick disease and chronic adult Gaucher's disease, there is an overwhelming preponderance of Ashkenazi Jews (Knudson \& Kaplan, 1962). Inheritance is generally recessive. There is some evidence that heterozygote carriers of Tay-Sachs disease have advantages in reproductive performance and survival when compared with normal individuals, and the same may also apply to Gaucher's and Niemann-Pick diseases (Myrianthopoulos \& Aronson, 1966). The relatively high incidence of Tay-Sachs disease may have initially been determined by the 'founder effect' due to the fortuitous presence of a heterozygote carrier for this disease among the original Jewish migrants who settled in Lithuania many generations ago (Livingstone, 1969) - doubtless this could apply to other conditions. The historical perspective of Gaucher's disease in Jews is entertainingly discussed by Groen (1964).

Abetalipoproteinaemia, a recessively transmitted disorder in which there is malabsorption, neuropathy, retinitis pigmentosa, acanthocytosis (a 'burr cell' malformation of the red cells) and absence of betalipoprotein from the serum, was first recognized in an American Jewish (and thus very likely Ashkenazi) family (Bassen \& Kornzweig, 1950; Kornzweig \& Bassen, 1957); the two affected sibs were the offspring of parents who were first cousins, and subsequent reports also favour recessive inheritance (Salt et al., 1960) Although McKusick (1966) considers this to be almost exclusively a disorder of Jews, his impression is not shared by Wolff (personal communication) who has seen four cases, none of them in Jews.

When another rare lipidosis (Wolman's disease) was described in three children of Persian Jewish parents who were first cousins (Wolman et al., 1961) it was thought that this might be a recessive disorder exclusive to Jews, but the disease has been reported in three unrelated white American gentiles of diverse origins (Crocker et al., 1965) and in Israeli Arabs (Wolman, 1968). Clinically, the disease resembles Hand-Schüller-Christian disease or eosinophilic granuloma; histologically the foamy histiocytes appear identical with those found in Niemann-Pick disease, but they contain triglycerides and cholesterol (Wolman, 1968). 
Phenylketonuria (PKU) is generally thought to be most characteristic of Northern European ethnic groups: thus if it were to occur in Jews one would suppose that the gene would most often be found in Ashkenazis. However, only one case has been reported in an Ashkenazi, a child born in America of non-consanguineous Russian immigrant parents (Cohen \& Kozinn, 1949). Paradoxically, the frequency of PKU in mentally retarded non-Ashkenazis in Israel $(1 \%)$ (Cohen et al., 1966) is of the same order as that found in the United Kingdom and America among non-Jewish patients (Cohen, Bodonyi \& Szeinberg, 1961); but there was not a single Ashkenazi case among the fifty-seven found in an extensive screening programme in Israel (Cohen \& Szeinberg, 1967); two Arab families were affected, the rest being Oriental or Sephardi Jews. Arabs are affected in the same frequency as Europeans (Salam, 1963). As with other cases of PKU, some affected Israelis are lighter in colour than their relatives (Laron, Yonis \& Bornstein, 1960), though many do have dark complexions and hair and brown eyes (Cohen et al., 1961). The metabolic block in nonAshkenazi Jews is identical to that found in Caucasians (Cohen \& Szeinberg, 1967. The apparent freedom of Ashkenazis is puzzling.

Glycinuria is increasingly recognized as a disorder of renal tubular transport occurring in both Orientals and Caucasians (Rosenberg, Durant \& Elsas, 1968) that may be quite benign. Among the Caucasians there has been a preponderance of Ashkenazis (Rosenberg et al., 1968; Whelan \& Scriver, 1968) though the Bulgarian family reported by De Vries et al. (1957) is Sephardic (De Vries, personal communication.).

The first case of tyrosinosis was reported in a Russian-born Jew found to have a reducing substance in the urine, the $\alpha$-ketoacid, $p$-hydroxyphenylpyruvic acid (Medes, 1932). This patient is often reported as being the only case described (McKusick, 1966) and the condition appeared quite benign. However, there are several other reports in which it appears that a more severe degree of tyrosinosis may be associated with hepatic and renal damage and hypophosphataemic rickets; it is found in non-Jews (Halvorsen \& Gjessing, 1964).

Wilson's disease (hepatolenticular degeneration) is a recessively transmitted disorder, of widespread occurrence that is rather more frequent in relatively isolated population groups. Thus it is not surprising that Bearn (1960) in New York found more cases of this disorder among Sicilians and Southern Italians, and Ashkenazi Jews from the Russo-Polish border area, than in other groups. The Jewish cases showed more evidence of consanguinity, a later onset (and thus greater fertility) and often had normal serum levels of copper and caeruloplasmin. While Wilson's disease is not a disorder predominantly affecting
Jews, there are reasons for expecting that it may occur more often in Jews whose ancestors lived in the Russian Pale of Settlement.

The Dubin-Johnson syndrome is a benign cause of jaundice in which there is an excess of conjugated bilirubin in the plasma, and dark pigment in the liver cells. Recognized throughout the world, and thought to be inherited as a dominant trait with incomplete penetrance, it has been found to be especially common in Iranian Jews now living in Israel (Shani et al., 1967). The frequency of the disorder is $1: 2000$ in Iranian Jews, as compared with $1: 250,000$ in other peoples; the incidence in the non-Jewish population of Iran has not been reported.

An endocrine disease once thought, on slender grounds, to occur more often in Jews is acromegaly (Rolleston, 1928) but further evidence for this belief has not been forthcoming.

\section{Blood}

When the first reports on polycythaemia appeared from America, a high incidence was noted in Jewish immigrants from Eastern Europe (Lucas, 1912) and this appeared to be corroborated by a study of polycythaemia vera in which an attempt was made to eliminate the ethnic bias inherent in the population structure of New York (Reznikoff, Foot \& Bethea, 1935). Subsequent studies have not substantiated these claims and polycythaemia vera does not appear to be especially common in Ashkenazis in Israel.

Haemophilia has often been considered to be unduly frequent in Jews (Rolleston, 1928), but this has not been borne out; it is of interest that it was recognized by Talmudical writers (Rosner, 1969). A bleeding disorder that does affect Jews more than others is factor XI (contact factor) deficiency (Nossel, 1964; Leiba, Ramot \& Many, 1965); a recent report of its probable occurrence in Africans does not appear fully substantiated (Forrest \& Wicks, 1968).

Familial neutropaenia is a benign disorder that tends to afflict Yemenite Jews (Alkan \& Feinaro, 1967) and that has been recognized in several patients of Adeni Jewish origin at the Prince of Wales's Hospital. It does not appear to be associated with disease or to have an adverse prognostic importance; it seems similar to the neutropaenia found in West Indians and Africans (Rippey, 1967; Shaper, Kyobe \& Stansfield, 1962).

Among Jews of Tunisian and Libyan origin, a recessively transmitted syndrome of selective vitamin $\mathrm{B}_{12}$ malabsorption, apparently due to lack of receptors to bind the $\mathbf{B}_{12}$-intrinsic factor complex prior to absorption, has been recognized by Ben-Bassat, Feinstein \& Ramot (1969): the associated, unexplained, proteinuria appears to be benign.

Various haemoglobinopathies are recognized in Oriental Jews, especially those from Bokhara 
(Schieber, 1945) and Kurdistan (the Biblical Assyria, where the first Jews were exiled from Israel in 722 B.C.) (Matoth, Shamir \& Freundlich, 1955) and $\beta$ and $\gamma$-thalassaemias have been identified, including Haemoglobin-H and Haemoglobin-Barts (Klibansky et al., 1960; Ramot et al., 1959). In addition, two unique $\alpha$-variants have been recognized in Ashkenazi and Oriental Jews-Haemoglobin-Beilinson (De Vries et al., 1963) and the rather similar Haemoglobin-Hasharon (Halbrecht et al., 1967)-and another unique $\alpha$-variant in Ashkenazis originating from the Polish-Lithuanian borders (Clejan et al., 1969).

The recognition of glucose-6-phosphate dehydrogenase deficiency (G-6-PDD) in Oriental Jews has been of great importance. Among Ashkenazi Jews the incidence of G-6-PDD is extremely low $(0.4 \%)$ and probably no higher than among Northern European populations generally, but in non-Ashkenazi Jews it varies from 1 to $2 \%$ among European Sephardis to $25 \%$ in Iraqi Jews, $28 \%$ in Caucasian Jews and $58 \%$ among Kurdish Jews (Sheba et al., 1962). It therefore seems likely that a mutation took place among the Judeans and Phoenicians living in the eastern Mediterranean area, and that it spread from them to other parts of the Mediterranean and Middle East and into the Moslems among whom they lived (Bowman \& Walker, 1961). Allison \& Clyde (1961) have suggested that G-6-PDD has persisted because it provides protection against $P$. falciparum malaria, but Sheba et al. (1962) and Bowman (1967) contest this. Sheba has advanced an intriguing theory for the prevalence of G-6-PDD in non-Ashkenazi Jews and its virtual absence from Ashkenazis: the former migrated from Israel with their families, whereas the latter are the descendants, he believes, of male captives taken to Rome after the destruction of the Second Temple. They were not accompanied by Jewesses and would have had to take wives from among non-Jewish slaves, from Illyria or across the Alps. As G-6-PDD is transmitted on the $\mathrm{X}$-chromosome, the trait would thus have been lost to the following generations.

G-6-PDD among Jews is similar to that occurring in other Mediterranean populations, and differs from the Negro variety found in Africa and America (Carson \& Frischer, 1966). Enzyme activity is $0-8 \%$ of normal and there is increased susceptibility to haemolysis upon exposure to a wide variety of drugs and agents that stress the oxidative reactions of the phosphate-pentose pathway, including antimalarials of the 8-aminoquinoline series (e.g. primaquine), sulphonamides, phenacetin, and exposure to the fava bean, Vicia faba (favism). However, haemolytic disease of the newborn does not appear to occur in Jews as it does in other Mediterranean peoples with G-6-PDD.
The importance of this disorder has been brought home to us at the Prince of Wales's Hospital because the population served by the hospital includes Oriental Jewish immigrants from Aden, Iraq and India, and a number of cases of G-6-PDD have been recognized among them; at least one has suffered from a drug-induced haemolytic anaemia.

\section{Nervous system}

The cerebral sphingolipidoses have already been discussed above. On the basis of personal impression and statements in textbooks, Jews are said to suffer unduly often from depression (Miller, 1967 and personal communication) and perseveration (Cattell, 1932). Social, as opposed to genetic, factors may possibly lead to the more overt expression of psychological symptoms by Ashkenazi Jews than by other Europeans. Multiple sclerosis in Jews appears to correlate with the latitude of origin (Alter et al., 1962) and socio-economic status (Antonovsky et al., 1967) rather than with genetic factors. In Israel the disease is more common among immigrants from Europe than from Africa or Asia; among native-born Israelis the prevalence is the same irrespective of the origin of their forebea-s (Leibowitz, Kahana \& Alter, 1969).

Anosmia has been described in Russian-Jewish families in association with hypogonadism (Kallman, Schoenfeld \& Barrera, 1944) or by itself (Glaser, 1918) due to agenesis of the olfactory lobes of the brain. These disorders may be X-linked, but the analysis of new causes that may be recognized and chromosome studies are obviously desirable. In familial dysautonomia, anosmia may be an associated symptom (Schneider, 1967). First reported by Riley et al. (1949), this recessively transmitted disorder typically affects a Jewish child who presents with dysphagia, recurrent pneumonia, poor motor co-ordination, absence of tears, hypotension and a number of other autonomic disturbances (Dancis \& Smith, 1966). All the Israeli cases are of Ashkenazi origin (Moses et al., 1967) and an overwhelming preponderance among Ashkenazis (as opposed to Gentiles) has likewise been noted in America by McKusick et al. (1967) who speculate that, as in Tay-Sachs disease, the heterozygote may confer a selective advantage. They estimate the frequency of dysautonomia in American Jews at between 1 in 10,000 and 1 in 20,000 births: one in fifty may carry the gene. Patients show an abnormal response to histamine and have abnormal taste buds; the fundamental defect remains unknown (Dancis \& Smith, 1966).

Dystonia musculorum deformans (primary torsion dystonia) is a rare disorder at first thought to be particularly common in Russian and Polish Jews (Zeman, Kaelbling \& Pasamanick, 1959) but now recognized in other groups, including French 
Canadians and Swedes (McKusick, 1966). Of great interest is the demonstration of superior intelligence in the recessively inherited form of this condition (Eldridge et al., 1970) and the possibility that effects like this may explain the intellectual and cultural achievements attributed to Ashkenazis (Snow, 1969).

Spongy degeneration of the nervous system is a rare disorder that affects the white matter, and causes atonia, blindness and mental defect, with death at an average age of 18 months; it appears to be recessively transmitted and to affect Eastern European Jews (Van Bogaert, 1963; Zu Rhein, Eichmann \& Puletti, 1960).

In a survey of deafness among children in Northern Israel, Winter \& Dar (1967) found a high incidence among North African Jews which they thought was largely genetic in origin, and often noted in the offspring of consanguineous marriages. In about $70 \%$ of cases, the deafness was recessively transmitted (Dar \& Winter, 1969). Deafness in association with albinism has been found in Moroccan Jews: Xlinked, with partial albinism (Ziprkowski et al., 1962), and recessive with total albinism (Ziprkowski \& Adam, 1964). Some of the latter families showed formes frustes with deafness alone. The conditions described by Ziprkowski do not appear closely to resemble the syndrome of deafness, partiallyexpressed albinism and facial anomalies, described by Waardenburg (1951), which is found in many races.

While myopia was mentioned by Sorsby \& Sorsby (1932) as being more common among Jews than others, this impression could not be sustained and is not repeated in a later review by one of these authors (Sorsby, 1953).

Anencephaly and spina bifida appear to occur infrequently in American and Israeli Ashkenazis, especially when compared with an Irish group; this may partly be due to socio-economic status, but ethnic factors seem independently important (Naggan \& MacMahon, 1967).

\section{Peripheral vascular system}

In many ways thromboangiitis obliterans (Buerger's disease) is the 'classical' disease attributed to Jews; but it occurs in all sections of the population, among Whites and also Negroes and Asians (Allen, Barker $\&$ Hines, 1962). Familial cases are extremely rare. The first large series was reported from New York, with its high population of Jewish immigrants from Eastern Europe, and the disease was thought to occur frequently, though not exclusively, in Russian and Polish Jews (Buerger, 1908). Now doubt has been cast on its existence as a specific entity (Wessler et al., 1960) and uncontrolled observations made in the past are not easily substantiated, nor can genetic or specific environmental mechanisms be invoked.

\section{Alimentary tract}

Ulcerative colitis appears to be more common in Jews than in Gentiles (Mendeloff et al., 1966; Weiner \& Lewis, 1960). Acheson \& Nefzger (1963) found the condition to be twice as frequent in Jewish soldiers in the American Army as in non-Jewish servicemen and that this was not related to their place of birth or residence; they felt that their results were consistent with a genetic susceptibility in Jews. In Israel, ulcerative colitis appears to occur or to be recognized less often than in England and Wales, and also to affect Ashkenazis more often than nonAshkenazis (Birnbaum, Groen \& Kallner, 1960).

According to Monk et al. (1967) the excessive incidence of ulcerative colitis in Jews cannot be attributed-certainly as far as their community study in Baltimore is concerned-to diagnostic bias or to a greater likelihood that Jews would be admitted to hospital or undergo more intensive study, although these aspects may play some role. In their study, Jews had an incidence two to four times higher than white Gentiles.

A similar Jewish preponderance appears to apply to Crohn's disease in America. At the Mayo Clinic, 163 out of 600 cases $(25.5 \%)$ were Jewish - apparently a disproportionate number according to patient attendance (Van Patter et al., 1954), and an even greater excess was noted in Detroit-forty-three of 100 cases (Ruble, Meyers \& Ashley, 1957). An excess of Jewish patients has also been reported by others (Acheson, 1960; Mendeloff et al., 1966; Monk et al., 1967) and a similar feature was found in children attending the Mayo Clinic (Van Heerden, Sigler \& Lynn, 1967). Again, diagnostic bias does not seem to be responsible for the excess. There do not appear to be published reports on this condition from Israel, with comparisons between Ashkenazi and Sephardi or Oriental Jewish groups. In both diseases, there appears to be an excess of Jewish patients, but they are by no means confined to Jews, although apparently several times more common in Jews than in non-Jews; the respective influence of genetic and environmental (e.g. psychosomatic) factors remains to be assessed.

Fibrocystic disease of the pancreas is more common in Ashkenazis than other Jews in Israel (Levin, 1963). The incidence of gluten sensitivity in Jews is not known, but the disorder is well recognized.

It was for many years believed that haemorrhoids were more prevalent among Jews: Friedenwald (1944) quoted a number of historical sources for this belief, with reasons given including cramped conditions, enforced sedentary life in the ghetto and, going back to 1305 , the theological basis propounded by Bernard de Gordon that this was due to 'divine vengeance' on the basis of Psalm 78, v.66-'. . . he smote his enemies in the hinder parts, he put them to a perpetual 
reproach.' It seems unlikely that so widespread a disorder of the Western world troubles Ashkenazi Jews more than other people from Europe.

\section{Skin}

Reference has already been made to cases of albinism, usually associated with deafness (Ziprkowski et al.,1962;Ziprkowski \& Adam, 1964). Numerous original and textbook reports suggesting an unduly high incidence of pemphigus vulgaris in Jews of Russian and Central European origin in New York are cited in a review by Brinn (1962) but this predilection has not been confirmed in Israel, and indeed one-third of the cases reported by Ziprkowski \& Schewach-Millet (1964) were non-Ashkenazi Jews.

\section{Multiple systems}

Precise classification of some diseases is difficult, and under this heading it is proposed to consider two disorders, both fairly recently recognized, with widespread effects, in which there is an increased tendency to affect different groups of Jews.

Familial Mediterranean fever (FMF) is the name given by Heller, Sohar \& Sherf (1958) to a syndrome first clearly recognized as an entity by Siegal (1945), and considered by Reimann (1948) as a form of 'Periodic Disease'. The syndrome has recently been extensively reviewed (Sohar et al., 1967) and consists of recurrent, self-limited, febrile episodes lasting perhaps a few days, and accompanied by pleurisy, peritonitis, arthralgia and skin eruptions, alone or in varying combinations. Despite the rapid and complete recovery from attacks, the condition is not benign; amyloidosis, of the peri-reticular variety (i.e. resembling secondary amyloidosis) is a frequent and sinister complication, causing progressive fatal nephropathy (Sohar et al., 1963); sometimes preceding the typical clinical expression of FMF and, albeit rarely, sometimes the sole manifestation. Neither the attacks of FMF nor the onset or progression of amyloidosis can be halted by any form of treatment. However, Eliakim (1970) considers that amyloidosis is a less frequent and less severe complication than reported, and has also found it to occur much less often among Ashkenazi cases; in FMF proteinuria does not necessarily indicate the onset of amyloidosis (Eliakim et al., 1970).

Careful studies by the Israeli workers have demonstrated an autosomal recessive pattern of inheritance (Sohar et al., 1967), with overwhelming predominance in certain population groups, viz. Sephardic and Oriental Jews, Armenians and Arabs. Most of their Jewish cases were of North African, Iraqi or Turkish origin. However, occasional cases were recognized among Ashkenazi Jews and this has been reported in other series (Siegal, 1964) and indeed in non-Jews of Western European origin (Dormer \& Hale, 1962).
There is still uncertainty about the existence as an entity of primary etiocholanolone fever, resembling FMFin several respects, yet not causing amyloidosis, but responding to corticosteroid therapy, and said to predominate in Ashkenazi Jews (Bondy, Cohn \& Gregory, 1965). The great frequency of FMF in non-Ashkenazi Jews and Armenians provokes speculation about possible historical connections in the distant past. The pathogenesis and aetiology of the disease are completely unknown.

Also recently recognized, affecting many parts of the body, and predominantly affecting Ashkenazi Jews, is Bloom's syndrome, which comprises congenital telangiectatic erythema (especially of the face), solar hypersensitivity, and stunted growth (Bloom, 1954). This very rare disorder has been shown sometimes to be accompanied by a wide range of congenital abnormalities (Bloom, 1966); and it is now becoming appreciated that the disease can be lethal. Of the twenty-three cases recognized, three have died, all from acute leukaemia, and in one of these chromosomal breakage was recognized before the onset of leukaemia (Sawitsky, Bloom \& German, 1966).

\section{Neoplastic disease}

It has for long been accepted that carcinoma of the penis is rare in Jews and this has been attributed to the religious custom of circumcision during infancy. It has also long been believed that this confers upon their marriage partners relative freedom from carcinoma of the cervix, but it is now known that the frequency of this neoplasm varies sharply among the different immigrant groups in Israel (Modan, Modan \& Sheba, 1967), being high in North African Jewesses (Steinitz, 1967). It seems likely that the low incidence of carcinoma of the cervix in Ashkenazi Jewesses can in part be explained by sociological factors, including later age of marriage, and fewer children (Coppleson, 1969; Stewart et al., 1966); on the other hand, in New York carcinoma of the body of the uterus is unduly frequent in Jewish women. Obviously more study of environmental and genetic factors is needed before the situation can be clarified.

Carcinoma of the colon seems more common among Jews in New York than among Gentiles; yet in Israel the incidence is much lower (Wynder \& Shigematsu, 1967). The frequency of carcinoma of the stomach and oesophagus varies among different groups of non-Ashkenazi Jews in Israel (Modan et al., 1967) and it seems likely that environmental factors are important. Carcinoma (and syphilis) of the tongue was thought to be rare in Jews (Sorsby \& Sorsby, 1932).

Studies in Israel have revealed a curious disorder affecting young Arabs and non-Ashkenazi Jews-a 
malabsorption syndrome associated with intestinal lymphoma (Ramot, Shahin \& Bubis, 1965; Eidelman, Parkins \& Rubin, 1966). Away from the lymphomatous areas, the bowel mucosa was abnormal, but these changes did not appear to be related to gluten sensitivity. Alimentary tract neoplasms are known to complicate idiopathic steatorrhoea (Gough, Read \& Naish, 1962; Harris et al., 1967), but the relationship to this 'Mediterranean' lymphoma syndrome is not established. A geographical factor, such as postulated in Burkitt's lymphoma, is possible. A possible clue may be in the discovery of an IgA abnormality, in which the protein is devoid of alphachains, in Arab and Eurasian patients with a lymphoma syndrome resembling that described from Israel, as well as in the only Israeli patient whose blood has been examined for this abnormality (Seligmann \& Rambaud, 1969). The results of family studies are now awaited; at present the aetiological factors remain undiscovered.

Unlike non-Ashkenazi Jews and Arabs, in whom lymphoma often affects young individuals and involves the alimentary tract, Ashkenazi Jews in Israel tend, like other Western populations, to be affected at an older age and to have peripheral lymphadenopathy (Ramot et al., 1964); childhood abdominal lymphoma is sometimes histologically similar to Burkitt's tumour (Hulu, Ramot \& Sheehan, 1970).

Kaposi's sarcoma used to be thought to be especially common in Jews from Central and Eastern Europe, and also Italians; but this impression may partly have been related to the proportions of these people among immigrants to America; a much wider range of peoples are affected (Bluefarb, 1957), and the disorder is now known to occur fairly frequently in Africans and not to be particularly common among Jews in Israel (Gordon, 1967). The only familial report of its occurrence is in the father and son of a Rumanian-Jewish family (Zeligman, 1960); the role of genetic factors in this disease is not established.

The recent claim that cancers in general are relatively infrequent in American (and therefore Ashkenazi) and Israeli Jewish men, in inverse proportion to diabetes, and that this is linked with G-6-PD deficiency (which is rare in American Jews) (Kessler, 1970) seems somewhat questionable.

\section{Miscellaneous}

More than 40 years ago Rolleston (1928) discussed apparent resistance of Jews to tuberculosis: but now one cannot assess how accurate were the data on which this impression is based. He likewise referred to alcoholism as a disease from which Jews rarely suffer; social factors are presumably responsible, and may still apply.
Of pharmacogenetic importance are several observations made in Jews. Pseudocholinesterase abnormality leading to sensitivity to suxamethonium, and rapid inactivation of isoniazid appear to occur in Israeli Jews, whether Ashkenazi or not, in the same proportion as in European populations (Szeinberg, 1963). According to Sheba, Israeli Jews do not appear prone to the haematological toxicity of chloramphenicol, but this view is not universally accepted (Crosby, 1969). Recently, several Israeli Jews of Afro-Asian origin have been shown not to be able to bind the antituberculosis drug ethambutol onto a blood component, and thus achieve therapeutic levels; this may be genetically determined (Lewit, Teracina \& Lewit, 1970). The most important of the pharmacogenetic associations is of course G-6-PD deficiency, already discussed; haemolysis due to acatalasia (deficiency of the enzyme catalase) may possibly occur, albeit rarely (Szeinberg, 1963).

There are numerous reports of the occasional occurrence of various physical quirks or rare disorders in Jews: obviously these cannot all be listed, but they include ovoid pupils in a Russian-Jewish mother and her identical twin daughters (White \& Fulton, 1937); persistence of deciduous (and absence of permanent) canines transmitted by autosomal dominant inheritance in a German-Jewish family (Gruneberg, 1936); dominant hereditary LeggCalvé-Perthe's disease (Wamoscher \& Farhi, 1963) in an Ashkenazi (Russian-Rumanian) family (Wamoscher, personal communication); and a recessive disorder of the red-cell membrane in a Polish-born Jewish family (Danon et al., 1962). These are interesting reports but too rare to enable any deductions about their significance to be made.

\section{Conclusions}

Many conditions thought to be common among Jews have turned out, on closer analysis, not to be so, and this includes disorders like diabetes mellitus, acromegaly, polycythaemia rubra vera and Kaposi's sarcoma. On the other hand, different Jewish populations appear to be predisposed to suffer from a variety of less well known disorders. In the case of the Ashkenazi Jews, certain cerebral sphingolipidoses, Bloom's syndrome, familial dysautonomia, and Wilson's disease, appear to be unduly common. The Ashkenazi Jews mainly affected have been derived from the Russian Pale of Settlement, largely along the Polish-Lithuanian borders, and in at least some cases there appears to be heterozygote advantage conferred upon the carriers which has perhaps favoured the survival and dissemination of the gene. On the other hand, among the Sephardic and Oriental Jewish population, there appears to be a greater incidence of genetic disorders related to inbreeding, in keeping with the social customs of the Middle 
East. Some disorders that appear to be unduly common among Ashkenazi Jews, e.g. ulcerative colitis and regional enteritis, have no demonstrable genetic background on the basis of present evidence; the intestinal lymphoma of Mediterranean type has been recognized too recently for it to be known whether it has an environmental or genetic aetiology. In Israel the social situation favours the mingling of the sub-sections of the Jewish population and this may well lead to the dilution of the effect of recessive genes. Those Jews who continue to live outside Israel, and who are predominantly Ashkenazi, will doubtless continue to remain exposed to these disorders. There is much scope for speculation as to how much the historical backgrounds of the various Jewish communities are responsible for these patterns of disease.

\section{References}

ACHeson, E.D. (1960) The distribution of ulcerative colitis and regional enteritis in United States veterans with particular reference to the Jewish religion. Gut, $1,291$.

ACHESON, E.D. \& Nefzger, M.D. (1963) Ulcerative colitis in the United States army in 1944. Epidemiology: comparisons between patients and controls. Gastroenterology, 44, 7.

AlKan, W.J. \& Feinaro, M. (1967) Familial neutropenia in Jews of Yemenite origin. Isracl Economist, 23, 81.

Allen, E.V., Barker, N.W. \& Hines, E.A., Jr (1962) Peripheral Vascular Diseases, 3rd edn. Saunders, Philadelphia and London.

Allison, A.C \& Clyde, D.F. (1961) Malaria in African children with deficient erythrocyte glucose-6-phosphate dehydrogenase. British Medical Journal, 1, 1346.

Alter, M., Halpern, L., Kurland, L.T., Bornstein, B.. Tikva, P., Leibowitz, U. \& Silberstein, J. (1962) Multiple sclerosis in Israel. Prevalence among immigrants and native inhabitants. Archives of Neurology (Chicago), 7, 253.

Antonovsky, A., Leibowitz, U., Medalie, J.M., Smith, H.A., Halpern, L. \& Alter, M. (1967) Epidemiological study of multiple sclerosis in Israel. Part III. Multiple sclerosis and socio-economic status. Journal of Neurology, Neurosurgery and Psychiatry, 30, 1.

Barnes, H.D. \& Bloomberg, B.M. (1953) Paper chromatography of the urinary sugar in essential pentosuria. South African Journal of Medical Sciences, 18, 93.

BASSEN, F.A. \& KornzWeIG, A.L. (1950) Malformation of the erythrocytes in a case of atypical retinitis pigmentosa. Blood, 5, 381.

BEARN, A.G. (1960) A genetical analysis of thirty families with Wilson's disease. (Hepatolenticular degeneration.) Annals of Human Genetics, 24, 33.

Ben-Bassat, I., Feinstein, A. \& Ramot, B. (1969) Selective vitamin $B_{12}$ malabsorption with proteinuria. Clinical and genetic aspects. Israel Journal of Medical Sciences, 5, 62.

BEN-ZVI, I. (1957) The Exiled and the Redeemed. Jewish Publishing Society of America, Philadelphia.

Birnbaum, D., Groen, J.J. \& Kallner, G. (1960) Ulcerative colitis among the ethnic groups in Israel. Archives of Internal Medicine, 105, 843.

Bцоом, D. (1954) Congenital telangiectatic erythema resembling lupus erythematosus in dwarfs. American Journal of Diseases of Children, 88, 754.

BLoom, D. (1966) The syndrome of congenital telangiectatic erythema and stunted growth. Observations and studies. Journal of Pediatrics, 68, 103.
Bluefarb, S.M. (1967) Kaposi's Sarcoma. Thomas, Springfield, Illinois.

Bondy, P.K., Cohn, G.L. \& Gregory, P.B. (1965) Etiocholanolone fever. Medicine (Baltimore), 44, 249.

Bowman, J.E. (1967) G.-6-P.D. deficiency and malaria. Lancet, $\mathbf{i}, 1158$.

Bowman, J.E. \& WALKer, D.G. (1961) The origin of glucose6-phosphate dehydrogenase deficiency in Iran: theoretical considerations. Proceedings of the Second International Congress of Human Geretics, Rcme, p. 583. Istituto G. Mendel, Rome.

BrinN, L.B. (1962) Jews, genetics and disease. Harofe Haivri, 2, 275.

BRunNer, D. \& MaNelis, G. (1960) Myocardial infarction among members of communal settlements in Israel. Lancet: ii, 1049.

Buerger, L. (1908) Thrombo-angiitis obliterans: a study of the vascular lesions leading to presenile spontaneous gangrene. American Journal of Medical Sciences, 136, 567.

CARSON, P.E. \& Frischer, H. (1966) Glucose-6-phosphate dehydrogenase deficiency and related disorders of the pentose phosphate pathway. American Journal of Medicine, 41, 744.

Cattell, R.B. (1935) Perseveration and personality. Some experiments and a hypothesis. Journal of Mental Sciences, 81, 151.

Clejan, L., Streifler, C , Sternbach, H., Frimerman, H. \& MenaChem, H. (1969) A new case of hemoglobin $\alpha$-Tp VI mutant in an Ashkenazi Jewish family. Israel Journal of Medical Sciences, 5, 1091.

CoHen, A.M. (1961) Prevalence of diabetes among different ethnic Jewish groups in Israel. Metabolism, 10, 50.

Cohen, B.E., Bodonyi, E. \& Szeinberg, A. (1961) Pheny!ketonuria in Jews. Lancet, i, 344.

CoHen, B.E. \& Szeinberg, A. (1967) Phenylketonuria. Seventh World Assembly of the Israel Medical Association.

Cohen, B.E., Szeinberg, A., Peled, I., Szeinberg, B. \& BAR-OR, R. (1966) Screening programme for the early detection of phenylketonuria in the newborn in Israel. Israel Journal of Medical Sciences, 2, 156.

CoHen, P. \& KozinN, P.J. (1949) Phenylpyruvic oligophrenia. Journal of Pediatrics, 34, 76.

Coppleson, M. (1969) Carcinoma of the cervix. Epidemio'ogy and aetiology. British Journal of Hospital Medicine, 2, 961 .

Crocker, A.C., Vawter, G.F., Neuhauser, E.B.D. \& RosowsKY, A. (1965) Wolman's disease: three new patients with a recently described lipidosis. Pediatrics, 35, 627.

CrosBy, W.H. (1969) Israelis not susceptible or simply too few? New England Journal of Medicine, 281, 1077.

DAHLBerg, G. (1952) The Swedish Jews: a discussion of the basic concept. Acta Genetica et Statistica Medica, 3, 106.

Dancis, J. \& SMITH, A.A. (1966) Current concepts: familial dysautonomia. New England Journal of Medicine, 274, 207.

Danon, D., de Vries, A., Dualdetti, M. \& Kirschmann, C (1962) Episodes of acute haemolytic anaemia in a patient with familial ultrastructural abnormality of the red cell membrane. British Journal of Haematology, 8, 274.

DAR, H. \& WiNTER, S.T. (1969) A genetic study of familial deafness. Israel Journal of Medical Sciences, 5, 1219.

de Vries, A., Joshua, H., Lehmann, H., Hill, R.L. \& Fellows, R.E. (1963) The first observation of an abnormal haemoglobin in a Jewish family: Haemoglobin Beilinson. British Journal of Haematology, 9, 484.

de Vries, A., Kochwa, S., Lazebnik, J., Frank, M. \& DJALDETTI, M. (1957) Glycinuria, a hereditary disorder associated with nephrolithiasis. American Journal of Medicine, 23, 408.

Dormer, A.E. \& HAlE, J.F. (1962) Familial Mediterranean fever, a cause of periodic fever. British Medical Journal, 1, 87. 
Dreyfus, F. (1953) The incidence of myocardial infarction in various communities in Israel. American Heart Journal, 45, 749.

DunN, L.C. \& DunN, S.P. (1957) The Jewish Community of Rome. Scientific American, 196, 119.

Eidelman, S., Parkins, R.A. \& Rubin, C.E. (1966) Abdominal lymphoma presenting as malabsorption: a clinicopathological study of nine cases in Israel and a review of the literature. Medicine (Baltimore), 45, 111.

Eldridge, R., Harlan, A., Cooper, I.S. \& Riklan, M. (1970) Superior intelligence in recessively inherited torsion dystonia. Lancet, i, 65.

EliAKIM, M. (1970) Incidence of amyloidosis in recurrent polyserositis (familial Mediterranean fever). Israel Journal of Medical Sciences, 6, 2.

Eliakim, M., Rachmilewitz, M., Rosenmann, E. \& Niv, A. (1970) Renal manifestations in recurrent polyserositis (familial Mediterranean fever). Israel Journal of Medical Sciences, 6, 228.

EPSTEIN, F.H. (1967) Risk factors in coronary heart disease. Environmental and hereditary influences. Israel Journal of Medical Sciences, 3, 594.

Epstein, F H., Boas, E.P. \& Simpson, R. (1957) The eipdemiology of atherosclerosis among a random sample of clothing workers of different ethnic origins in New York City. I. The prevalence of atherosclerosis and some associated characteristics. Journal of Chronic Diseases, 5, 300.

EPSTEIn, F.H., Simpson, R. \& BoAS, E.P. (1957) The epidemiology of atherosclerosis among a random sample of clothing workers of different ethnic origins in New York City. II. Associations between manifest atherosclerosis, serum lipid levels, blood pressure, overweight, and some other variables. Journal of Chronic Diseases, 5, 329.

FISHBERg, M. (1911) The Jews: a Study of Race and Environment, p. 107. Walter Scott Publishing Company, London.

ForResT, M.G.A. \& Wicks, A.C.B. (1968) Probable factor XI deficiency in Bantu subjects. South African Medical Journal, 42, 747.

FREDRICKSON, D.S. \& LEES, R.S. (1966) Familial hyperlipoproteinemia. In: The Metabolic Basis of Inherited Disease (Ed. by J. B. Stanbury, J. B. Wyngaarden and D. S Fredrickson), p. 429. McGraw-Hill, New York.

Friedenwald, H. (1944) The Jews and Medicine, Vol. II. Johns Hopkins Press, Baltimore.

GARROD, A.E. (1908) Inborn errors of metabolism. Lancet, ii, 214.

GlaSER, O. (1918) Hereditary deficiencies in the sense of smell. Science, 48, 647.

GoldsChMid, E. (Ed.) (1963). The Genetics of Migrant and Isolate Populations. Williams \& Wilkins, Baltimore.

GoRDON, H. (1965) Genetics and Race, part II. South African Medical Journal, 39, 543.

GoRDon, J.A. (1967) Kaposi's sarcoma: a review of 136 Rhodesian African cases. Postgraduate Medical Journal, 43, 513.

Gough, K.R., Read, A.E. \& NaISH, J.M. (1962) Intestinal reticulosis as a complication of idiopathic steatorrhoea. Gut, 3, 232.

Groen, J.J. (1964) Gaucher's disease. Hereditary transmission and racial distribution. Archives of Internal Medicine, 113, 543.

GruneberG, H. (1936) Two independent inherited tooth anomalies in one family, Journal of Heredity, 27, 225

Halbrecht, I., IsaAcs, W.A., LehmanN, H. \& Ben-Porat, F. (1967) Hemoglobin Hasharon ( $\alpha 47$ Aspartic acid $\rightarrow$ histidine). Israel Journal of Medical Sciences, 3, 827.

Halvorsen, S. \& GJEssing, L.R. (1964) Studies of tyrosinosis. I. Effect of a low-tyrosine and low-phenylalanine diet. British Medical Journal, 2, 1171.

Harris, O.D., CoOKe, W.T., Thompson, H. \& Waterhouse, J.A.H. (1967) Malignancy in adult coeliac diseases and idiopathic steatorrhoea. American Journal of Medicine, 42, 899.

Heller, H., Solar, E. \& Sherf, L. (1958) Familial Mediterranean fever. Archives of Internal Medicine, 102, 50.

Hulu, N., Ramot, B. \& Sheehan, W. (1970) Childhood abdominal lymphoma in Israel. Israel Journal of Medical Sciences, 6, 246.

KallmanN, F.J., Schonfeld, W.A. \& Barrera, S.E. (1944) Genetic aspects of primary eunuchoidism. American Journal of Mental Deficiency, 48, 203.

Kessler, I. (1970) A genetic relationship between diabetes and cancer. Lancet, $\mathbf{i}, 218$.

Khachadurian, A.H. (1962) Essential pentosuria. American Journal of Human Genetics, 14, 249.

Klibansky, C., Dualdetti, M., Joshua, H. \& de Vries, A. (1960) Hemoglobin-H thalassemia in a Sephardic Jewish family from Turkey. Israel Medical Journal, 19, 199.

KnuDson, A.G., Jr \& KAPLAN, W.D. (1962) Genetics of the sphingolipidoses. In: Cerebral Sphingolipidoses. (Ed. by S. M. Aronson and B. W. Volk), p. 407. Academic Press, New York.

Kornzweig, A.L. \& Bassen, F.A. (1957) Retinitis pigmentosa, acanthrocytosis, and heredodegenerative neuromuscular disease. Archives of Ophthalmology, 58, 183.

KRIKLER, D.M. (1969) Diabetes in Rhodesian Sephardic Jews. South African Medical Journal, 43, 931.

Laron, S., Yonis, Z. \& Bornstein, B. (1960). Phenylketonuria in Jews. Pediatrics, 26, 885.

Leiba, H., Ramot, B. \& MaNY, A. (1965) Heredity and coagulation studies in ten families with factor XI (plasma thromboplastin antecedent) deficiency. British Journal of Haematology, 11, 654.

Leibowitz, U., Kahana, E. \& Alter, M. (1969) Multiple sclerosis in the immigrant and native populations of Israel. Lancet, ii, 1323.

Levin, S. (1963) Fibrocystic disease of the pancreas. In: The Genetics of Migrant and Isolate Populations (Ed. by E. Goldschmidt), p. 294. Williams and Wilkins, Baltimore.

Levin, S., Moses, S.W., Chayoth, R., Jagoda, N. \& SteINITZ, K. (1967) Glycogen storage disease in Israel. A clinical biochemical and genetic study. Israel Journal of Medical Sciences, 3, 397.

Lewit, T., Terracina, S. \& Lewit, R. (1970) Spurious resistance to ethambutol. Lancet, ii, 99 .

Livingstone, F.B. (1969) The founder effect and deleterious genes. American Journal of Physical Anthropology, 30, 55.

LUCAS, W.S. (1912) Erythremia, or polycythemia with chronic cyanosis and splenomegaly. Archives of Internal Medicine, 10, 597.

McKusick, V.A. (1966) Mendelian Inheritance in Man. Heinemann, London.

McKusick, V.A., Norum, R.A., Farkas, H.J., Brunt, P.W. \& Mahljoudi, M. (1967) The Riley-Day Syndromeobservations on genetics and survivorship. An interim report. Israel Journal of Medical Sciences, 3, 372.

Matoth, Y., Shamir, Z. \& Freundlich, E. (1955) Thalassemia in Jews from Kurdistan. Blood, 10, 176.

Medes, G. (1932) A new error of tyrosine metabolism: tyrosinosis. The intermediary metabolism of tyrosine and phenylalanine. Biochemical Journal, 26, 917.

Mendeloff, A.I., Monk, M., Siegel, C.I. \& Lilienfeld, A. (1966) Some epidemiological features of ulcerative colitis and regional enteritis. Gastroenterology, 51, 748.

Miller, H. (1967) Depression. British Medical Journal, 1, 257.

Modan, B., Modan, M. \& Sheba, C. (1967) Uterine cancer. Lancet, i, 336.

Monk, M., Mendeloff, A.I., Siegel, C.I. \& Lilienfeld, A. (1967) An epidemiological study of ulcerative colitis and regional enteritis among adults in Baltimore. I. Hospital incidence and prevalence, 1960 to 1963. Gastroenterology, 53, 198 . 
Moses, S.W., Rotem, Y., JAgoda, N., TAlmor, N., EICHHORN, F. \& LeVIN, S. (1967) A clinical, genetic and biochemical study of familial dysautonomia in Israel. Israel Journal of Medical Sciences, 3, 358.

Myrianthopoulos, N.C. \& Aronson, S.M. (1966) Population dynamics of Tay-Sachs disease. I. Reproductive fitness and selection. American Journal of Human Genetics, 18, 313.

Naggan, L. \& MacMahon, B. (1967) Ethnic differences in the prevalence of anencephaly and spina bifida in Boston, Massachusetts. New England Journal of Medicine, 277, 1119.

Nossel, H.L. (1964) The Contact Phase of Blood Coagulation, p. 42. Blackwell Scientific Publications, Oxford.

PerRY, T.L. \& Finch, C.A. (1967) Pentosuria in a North American Indian. Nature, 216, 1027.

Politzer, W.M. \& FleischmanN, H. (1962) L-Xylulosuria in a Lebanese family. American Journal of Human Genetics, 14, 256.

Ramot, B., Frand, U., Leiba, H. \& Many, A. (1964) The expressivity of malignant lymphoma in different Jewish ethnic groups and Arabs. Proceedings of the Tenth Congress of the International Society of Haematology, p. 000.

Ramot, B., Shahin, N. \& Bubis, J.J. (1965) Malabsorption syndrome in lymphoma of the small intestine. A study of 13 cases. Israel Journal of Medical Sciences, 1, 221.

Ramot, B., Sheba, C., Fisher, S., Ager, J.A.M. \& Lehmann, H. (1959) Haemoglobin-H disease with persistent haemoglobin 'Bart's' in an oriental Jewess and her daughter: a dual $\alpha$-chain deficiency of human haemoglobin. British Medical Journal, 2, 1228.

ReimanN, H.A. (1948) Periodic disease; probable syndrome including periodic fever, benign paroxysmal peritonitis, cyclic neutropenia and intermittent arthralgia. Journal of the American Medical Association, 136, 239.

Reznikoff, P., Foot, N.C. \& Bethea, J.M. (1935) Etiologic and pathologic factors in polycythemia vera. American Journal of Medical Sciences, 189, 753.

Riley, C.M., DAY, R.L., GreEley, D.M. \& LANGFord, W.S. (1949) Central autonomic dysfunction with defective lacrimation. I. Report of five cases. Pediatrics, 3, 468.

RipPEY, J. J. (1967) Leucopenia in West Indians and Africans. Lancet, ii, 44.

Rolleston, H. (1928) Some diseases in the Jewish race. Bulletin of the Johns Hopkins Hospital, 43, 117.

Rosenberg, L.E., Durant, J.L. \& Elsas, L.J., II. (1968) Familial iminoglycinuria: an intorn error of renal tubular tranport. New England Journal of Medicine, 278, 1407.

ROSNER, F. (1969) Hemophilia in the Talmud and rabbinic writings. Annals of Internal Medicine, 70, 833.

Ruble, P.E., Meyers, S.C. \& Ashley, L.B. (1957) Regional enteritis. Harper Hospital Bulletin, 15, 142.

Salam, M. (1963) Phenylketonuria in a child from the Middle East. American Journal of Diseases of Children, 105, 102

Salt, H.B., Wolff, O.H., Lloyd, J.K., Fosbrook, A.S., CAmeron, A.H. \& Hubble, D.V. (1960) On having no Beta-Lipoprotein. A syndrome comprising A- $\beta$-Lipoproteinaemia, Acanthocytosis and Steatorrhoea. Lancet, ii, 325.

Sawitsky, A., Bloom, D. \& German, J. (1966) Chromosomal breakage and acute leukemia in congenital telangiectatic erythema and stunted growth. Annals of Internal Medicine 65, 487 .

Schaefer, L.E., Drachman, S.R., Steinberg, A.G. \& Adlersberg, D. (1953) Genetic studies on hypercholesteremia: frequency in a hospital population and in families of hypercholesteremic index patients. American Heart Journal, 46, 99.

Schieber, C. (1945) Target cell anaemia. Two cases in Bucharan Jews. Lancet, ii, 851.
SCHNEIDER, R.A. (1967) The sense of smell in man-its physiologic basis. New England Journal of Medicine, 277, 299.

SeligmanN, M. \& Rambaud, J.C. (1969) IgA abnormalities in abdominal lymphoma ( $\alpha$-chain disease). Israel Journal of Medical Sciences, 5, 151.

Shani, J., Gilon, A., Ben-Ezer, J. \& Sheba, C. (1967) Dubin-Johnson disease in Israel. Seventh World Assembly of the Israel Medical Association.

ShaPer, A.G., KyOBe, J. \& STANSfield, D.E. (1962) Haematological observations in an East African student population. East African Medical Journal, 39, 1.

ShapIRo, H.L. (1960). The Jewish people. A Biological History. Unesco, Paris.

SHEBA, C. (1968) Reconstructing Jewish migration with the aid of biochemical tests. A working hypothesis. Proceedings of the Tel-Hashomer Hospital, 7, 91.

Sheba, C., Szeinberg, A., Ramot, B., Adam, A. \& AshkeNAZI, I. (1962) Epidemiological survey of deleterious genes in different population groups in Israel. American Journal of Public Health, 52, 1101.

Siegal, S. (1945) Benign paroxysmal peritonitis. Annals of Internal Medicine, 22, 1.

Siegal, S. (1964) Familial paroxysmal polyserositis. American Journal of Medicine, 36, 893.

Snow, C.P. (1969) Letter to The Times (11 April, 1969).

Sohar, E., Gafni, J., Blum, A., Pras, M. \& Heller, H. (1963) Primary perireticular ('typical') amyloidosis in Israel: its relation to familial Mediterranean fever. Quarterly Journal of Medicine, 32, 211.

Sohar, E., Gafni, J., Pras, M. \& Heller, H. (1967) Familial Mediterranean fever. A survey of 470 cases and review of the literature. American Journal of Medicine, 43, 227.

SorsBy, A. (1953) Clinical Genetics, p. 350. Butterworth, London.

Sorsby, A. \& Sorsby, M. (1932) Racial diseases of Jews. Jewish Review, 1, 59.

SteINITZ, R. (1967) Uterine cancer. Lancet, i, 447.

Stewart, H.L., Dunham, L.J., CaSPER, J., Dorn, H.F. Thomas, L.B., Edgcomb, J.H. \& Symeonidis, A. (1966) Epidemiology of cancers of uterine cervix and corpus. breast and ovary in Israel and New York City. Journal of the National Cancer Institute, 37, 1 .

SzeinberG, A. (1963) Pharmacogenetics: inherited differences in drug sensitivity-studies of the Jewish population in Israel. Harokeach Haivri, 9, 672.

VAN BOGAERT, L. (1963) Familial spongy degeneration of the brain. Acta psychiatrica Scandinavica, 39, 107.

Van Heerden, J.A., Sigler, R.M. \& LynN, H.B. (1967) Regional enteritis in children: surgical aspects. Mayo Clinic Proceedings, 42, 100.

VAN Patter, W.N., Bargen, J.A., Dockerty, M.B. Feldman, W.H., Mayo, C.W. \& Waugh, J.M. (1954) Regional enteritis. Gastroenterology, 26, 353.

Vlodaver, Z., Kahn, H.A. \& Neufeld, H.N. (1969) The coronary arteries in early life in three different ethnic groups. Circulation, 39, 541.

WAARDENBURG, P.J. (1951) A new syndrome combining developmental anomalies of the eyelids, eyebrows, and nose root, with pigmentary defects of the iris and head hair and with congenital deafness. American Journal of Human Genetics, 3, 195.

WAMoscher, Z. \& FARHI, A. (1963) Hereditary LeggCalvé-Perthes disease. American Journal of Diseases of Children, 106, 97.

Weiner, H.A. \& Lewis, C.M. (1960) Some notes on the epidemiology of non-specific ulcerative colitis. An apparent increase in incidence in Jews. American Journal of Digestive Diseases, 5, 406.

Wessler, S., Ming, S.-C., Gurewich, V. \& Freiman, D.G, (1960). A critical evaluation of thrombo-angiitis obli- 
terans: the case against Buerger's disease. New England Journal of Medicine, 262, 1149.

Whelan, D.T. \& SCRIVER, C.R. (1968) Cystathioninuria and renal iminoglycinuria in a pedigree. New England Journal of Medicine, 278, 924.

White, B.V. \& Fulton, M.N. (1937) A rare pupillary defect inherited by identical twins. Journal of Heredity, 28, 177.

WINTER, S.T. \& DAR, H. (1967) Deafness among children in Northern Israel. Incidence and etiology. Israel Journal of Medical Sciences, 3, 894.

Wolman, M. (1968) Primary familial xanthomatosis with involvement and calcification of the adrenals (Wolman's disease). Proceedings of the Tel-Hashomer Hosiptal, 7, 1.

Wolman, M., Sterk, V.V., Gatt, S. \& Frenkel, M. (1961) Primary familial xanthomatosis with involvement and calcification of the adrenals. Pediatrics, 28, 742.

Wynder, E.L. \& Shigematsu, T. (1967) Environmental factors of cancer of the colon and rectum. Cancer, 20, 1520.
Zeligivan, I. (1960) Kaposi's sarcoma in a father and son. Bulletin of the Johns Hopkins Hospital, 107, 208.

Zeman, W. Kaelbling, R. \& Pasamanick, B. (1959) Idiopathic dystonia musculorum deformans. I. The hereditary pattern. American Journal of Human Genetics, 11, 188.

ZIPRKOWSKI, L. \& ADAM, A. (1964) Recessive total albinism and congenital deaf-mutism. Archives of Dermatology, 89, 151.

Ziprkowski, L., Krakowski, A., Adam, A., Costeff, H. \& SADE, J. (1962) Partial albinism and deaf mutism due to a recessive sex-linked gene. Archives of Dermatology, 86, 530.

Ziprkowski, L. \& Schewach-Millet, M. (1964) A longterm study of pemphigus. Proceedings of the Tel-Hashomer Hospital, 3, 46.

Zu Rhein, G.M., Eichman, P.L. \& Puletti, F. (1960) Familial idiocy with spongy degeneration of the central nervous system of Van Bogaert-Bertrand type. Neurology, $10,998$. 